Board of Governors of the Federal Reserve System

International Finance Discussion Papers

Number 508

April 1995

\title{
IMPORT PRICES AND THE COMPETING GOODS EFFECT
}

Phillip Swagel

NOTE: International Finance Discussion Papers are preliminary materials circulated to stimulate discussion and critical comment. References in publications to International Finance Discussion Papers (other than an acknowledgment that the writer has had access to unpublished material) should be cleared with the author or authors. 


\section{$\underline{\text { ABSTRACT }}$}

I use disaggregated U.S. data from 1978 to 1988 to examine the impact of changes in the prices of imported manufactured goods on corresponding domestic prices--the "competing goods effect." I use an econometric specification which allows for product differentiation between domestic and imported goods, and provides measures of exchange rate pass-through and economies of scale.

I find that the impact of import prices on domestic prices varies substantially by industry, with statistically significant effects in nine of nineteen two-digit SIC manufacturing categories. However, even where the effects are statistically significant, they are typically small in economic terms. On the whole, I do not find support for the anecdotal evidence that firms in US manufacturing industries take advantage of the reduced competitive discipline of higher import prices. Because import prices are not a substantial determinant of domestic prices ir. the U.S., this implies that the consequent danger of imported inflation is small. 


\title{
Import Prices and the Competing Goods Effect
}

\author{
Phillip Swagel ${ }^{1}$
}

\section{Introduction}

The continuing weakness of the dollar has brought renewed concern about imported inflation, both from increases in the prices of imports themselves as well as from sympathetic increases in the prices of import-competing domestic goods. The automobile industry is often cited as an example of this "competing goods effect," in that the strength of the yen against the dollar has increased Japanese exporters' dollar-denominated costs and thus the prices of imported cars. These price increases have allegedly given domestic firms competitive breathing room under which to raise their own prices.

Somewhat mitigating this concern is the now well-established phenomenon of pricingto-market, in which foreign firms allow their price-cost markups to vary, so that import prices adjust less-than-proportionately to changes in exchange rates. This incomplete pass-through of exchange rate shocks is often put forward as an explanation for the slow adjustment of the U.S. trade balance in response to the post-1985 depreciation of the dollar.

In the context of overall prices, by reducing the response of import prices to exchange

\footnotetext{
${ }^{1}$ The author is a visiting assistant professor at Northwestern University. I am grateful to Joe Gagnon, Bill Helkie, Judy Hellerstein, Dale Henderson, Peter Hooper, Cathy Mann, Will Melick, Charles Sawyer, Dan Trefler, Ted Truman, and seminar participants at McGill, the Chicago Fed, and the 1995 AEA meetings for helpful comments and discussions, to John Fernald and Jack Hervey for discussions and generously providing data, and particularly to Mike Knetter for extensive comments and suggestions. Parts of this paper were written while the author was a staff economist at the Federal Reserve Board and a visiting scholar at the Chicago Fed. However, the opinions expressed in this paper are solely those of the author, and are not necessarily shared by the Federal Reserve System or its staff.
} 
rates, imperfect pass-through dampens the direct effect of an exchange rate shock on measured inflation. In the U.S., moreover, this direct effect is relatively small to begin with, as merchandise imports account for only a modest share of consumption. ${ }^{2}$ However, the competing goods effect provides an additional channel through which an exchange rate shock (or any other shock to import prices such as changes in trade barriers) can affect domestic inflation, since even a small amount of imported inflation is magnified to the extent to which it leads to corresponding increases in prices by import-competing domestic firms.

In this paper I use a panel of disaggregated manufacturing industries from 1978 to 1988 to examine the impact of changes in the prices of imported manufactured goods on corresponding U.S. prices--the "competing goods effect." Along the lines of the pass-through literature, I estimate pricing equations for domestic and foreign firms competing in the U.S. market. An innovation of this paper is that I augment the pricing equations with a cost function for domestic firms. This provides an integrated framework in which to obtain measures of the interactions between import prices and domestic prices, exchange rate passthrough, and returns to scale.

I find that the effect of import prices on domestic prices varies substantially by industry, with statistically significant effects in nine of nineteen two-digit SIC marufacturing categories: food, textiles, chemicals, petroleum, leather, primary metals, non-electrical machinery, transport equipment, and miscellaneous manufactures. Except in the leather industry, however, these effects, though statistically significant, are fairly small in economic

${ }^{2}$ From the January 1994 Survey of Current Business, 1993 GDP measured in 198; dollars totalled $\$ 5,132.7$ billion, of which merchandise imports accounted for $\$ 572.3$ billion, or just over $11 \%$. 
terms. In the other ten industries, I find effects which are both small in magnitude and not statistically significant. On the whole, I conclude that there is only a small "competing goods effect" in U.S. manufacturing industries. Because import prices are not a substantial determinant of domestic prices in the U.S., this implies that the consequent danger of imported inflation is small.

The rest of the paper proceeds as follows. The next section discusses the exchangerate pass-through literature, focusing particularly on previous work on the spillover effects of import prices into domestic prices. In Section III, I then present the model of firms' costs and prices and discuss the estimation framework. I describe the data in Section IV, followed by estimation results in Section V. Section VI provides sensitivity analysis, after which Section VII concludes with implications of my results.

\section{The Literature on Prices and Exchange Rate Pass-Through}

There is a large literature on the incomplete pass-through of exchange-rates to import prices ard the related phenomenon of pricing to market. Mann (1986) provided the initial evidence that foreign firms partially absorbed the mid-1980's appreciation and decline of the dollar in their profits rather than changing their dollar-denominated prices to fully reflect movements in exchange rates. Dixit (1989), Krugman and Baldwin (1987), Fisher (1989), and Frocit and Klemperer (1989) provide theoretical explanations for this phenomenon, focusing variously on the roles of sunk costs, imperfect competition, and market share. Hooper and Mann (1989) review the analytical framework underlying the empirical passthrough literature and estimate aggregate pass-through equations for U.S. imports of 
manufactures; they find that only 50 to 60 percent of exchange rate changes is passed through to import prices. A number of authors, including Giovannini (1988), Knetter $(1989,1993)$ and Marston (1990) demonstrate the existence of pricing to market for various disaggregated industries. $^{3}$

Compared to the literature on the pass-through of exchange rates to import-prices, there is relatively little work on the effects of import prices on domestic prices. Ceglowski (1992) and Feinberg (1993) estimate price equations for imports and domestic goods jointly, allowing for their simultaneous determination. Ceglowski finds generally insignificant coefficients for both the effect of import prices on domestic prices as well as the effect of domestic prices on import prices. For industries in which significant coefficients are found, they indicate that domestic prices influence import prices but not the other way around. Feinberg, on the other hand, finds nearly the opposite, that the effect of import prices on domestic prices is larger (in a particular sense) than the effect of exchange rates on import prices. However, neither of these papers includes a formal equation for costs, relying instead on various ad-hoc proxies such as labor costs alone.

Rather than estimating the competing goods effect directly, Knetter (1994) adds dummies for periods in which the dollar was strong to an equation for pass-through of exchange rates to import prices in a number of disaggregated goods. Though his results are mixed, he finds some evidence that the strong dollar was associated with more competitive behavior in U.S. markets, which he interprets as coming from stiffer import competition.

\footnotetext{
${ }^{3}$ This brief discussion mentions only a fraction of what is now an enormous literature, both theoretical and especially empirical.
} 
Also clcsely related are the papers of Harrison (1993) and Levinsohn (1992), who use panels of firm-level data to examine the effect of trade liberalization on domestic firms' price-cost markups in the Ivory Coast and Turkey, respectively. They each find that price-cost markups fell in years following trade reforms. Although markets in both countries are much smaller than those in the U.S., these results tie in well with Feenstra (1989), who finds that foreign firms exporting to the U.S. respond symmetrically in their markup behavior to price shocks from both trade barriers and exchange rate shocks--that is, a strong (weak) dollar results in greater (less) competitive pressure from imports.

\section{Exchange Rates, Import Prices, and Domestic Prices}

As discussed above, the pass-through literature for the most part looks at the effect of exchange rates on import prices. This is natural, since the original impetus for the focus on exchange rate pass-through was to explain the puzzling behavior of import quantities, particularly the slow decline of the U.S. trade deficit following the early 1980's appreciation of the dollar. If domestic goods and imports are imperfect substitutes, however, a depreciation of the dollar will have two effects on the prices faced by domestic consumers: the direct effect of higher prices for imported goods, along with possibly higher prices for domestic goods if import-competing firms in the United States take advantage of the reduced competitive discipline of higher import prices to raise their own prices. ${ }^{4}$

\footnotetext{
${ }^{4}$ This effect is magnified yet again if we allow for imported intermediates, since this means that higher import prices leads to directly higher domestic costs and thus an additional increase in domestic prices. For the steel industry, Harrison (1992) shows that much of the apparent lack of responsiveness of import prices to exchange rates resulted not from imperfect competition and pricing to market, but instead from the use of dollar-denominated inputs by foreign steel firms which offset a large part of exchange rate movements.
} 
To summarize, the total effect on domestic prices depends on both excharige-rate passthrough as well as on the competing goods effect:

$$
\frac{\Delta \text { domestic price }}{\Delta \text { exchange rate }}=\frac{\Delta \text { domestic price }}{\Delta \text { import price }} \times \frac{\Delta \text { import price }}{\Delta \text { exchange rate }}
$$

The pass-through literature discussed in the previous section looks primarily at the second term on the right-hand-side; I examine both, allowing for simultaneity between import prices and domestic prices. These are explored in the model below, which closely follows Feenstra (1989) and Feenstra, Gagnon, and Knetter (1993).

A single U.S. firm and foreign firm compete in an industry in the U.S. market, producing quantities $\mathrm{Q}$ and $\mathrm{Q}^{*}$, respectively, where the two goods are imperfect substitutes in demand. The U.S. firm sets its price, P, to maximize profits, $\pi$ :

$\max \pi=P Q\left(P, P^{*}, Y\right)-T C(Q)$

where $\mathrm{TC}(\mathrm{Q})$ is the total cost of production and $\mathrm{Y}$ is total income (GDP). The assumption of imperfect substitutes means that the domestic quantity, $\mathrm{Q}$, is a function of both $\mathrm{P}$ and the price of the foreign good, $\mathrm{P}^{*}$. The foreign firm similarly chooses its price in dollars, $\mathrm{P}^{*}$, to maximize profits $\pi^{*}$ :

$$
\max \pi^{*}=P^{*} Q^{*}\left(P, P^{*}, Y\right)-T C^{*}\left(Q^{*}\right) / E
$$

where $\mathrm{E}$ is the exchange rate measured in foreign currency per dollar (so that $\mathrm{E}$ rises when the dollar appreciates), and $\mathrm{TC}^{*}\left(\mathrm{Q}^{*}\right)$ is foreign total costs in foreign currency. The formulation in terms of $\mathrm{TC}^{*} / \mathrm{E}$ makes clear the sense demonstrated by Feenstra (1989) in 
which exchange rate movements represent a cost shock to the foreign firm.

Profit-maximization gives the first-order conditions:

$$
\begin{array}{ll}
Q+(P-C) Q_{P} & =0 \\
Q^{*}+\left(P^{*}-C^{*} / E\right) Q_{P^{*}}^{*} & =0
\end{array}
$$

where $\mathrm{C}$ and $\mathrm{C}^{*}$ are marginal costs. Assuming Bertrand behavior and rearranging the firstorder conditions gives the usual condition that price is a markup, $\mu$, over marginal costs. The markup for domestic firms is $\mu=\eta /(\eta-1)$, where $\eta$ denotes the elasticity of demand for the domestic: good, while the foreign markup depends analogously on the elasticity of demand for the foreign good, $\mu^{*}=\eta^{*} /\left(\eta^{*}-1\right) .^{5}$ With goods which are imperfect substitutes, demand elasticities of course depend on the prices of both goods, so that the first-order conditions imply that the price of either good depends not only on costs and income, but also on the price of the competing goods:
(1) $P=P\left(P^{*}, C, Y\right)$
(2) $P^{*}=P^{*}\left(P, C^{*} / E, Y\right)$

As discussed in the Section IV below, industry-level cost and gross output data are available for domestic goods, though not for imports. The next step, then, is to parametrize domestic total costs, TC, and derive domestic marginal costs, C. I assume that the firm is a

${ }^{5}$ Allowing for a mode of competition between firms other than Bertrand would result in a more complicated expression for the price-cost markup, since this would include non-zero conjectural variations terms. The implications for my empirical results are discussed below. 
price-taker in factor markets, and specify a Cobb-Douglas functional form for costs:

$$
T C=A t^{\theta} P_{k}^{\alpha_{k}} P_{p}^{\alpha_{p}} P_{n}^{\alpha_{e}} P_{e}^{\alpha_{e}} P_{m}^{\alpha_{m}} Q^{\gamma}
$$

where $A$ denotes the initial level of technology, $t$ is a time counter which parametrizes technological progress, $\gamma$ denotes the quantity elasticity of costs, and $P_{i}$ are the costs of the five factors of production: capital (k), production workers (p), non-production workers (n), energy (e), and materials other than energy (m). A value of $\gamma=1$ indicates constant returns to scale (CRS), while $\gamma<1$ implies increasing returns, since this means that total costs rise by less proportionately than output. This might arise, for example, if there is underutilized capacity in production. Taking the derivative of the cost function with respect to output, $Q$, then gives marginal cost, $C$ :

$$
C=\gamma A t^{\theta} P_{k}^{\alpha_{k}} P_{p}^{\alpha_{p}} P_{n}^{\alpha_{e}} P_{e}^{\alpha_{e}} P_{m}^{\alpha_{m}} Q^{\gamma-1}
$$

Since cost data are not available for disaggregated imports, I assume constant marginal costs for foreign firms, with dollar-denominated foreign costs depending on exchange rates (which are imperfectly passed-through) and the initial level and growth of technology (that is, the passage of time) within each industry:

$$
C^{*} / E=A^{*} t^{\theta^{*}} E^{-\phi}
$$

Following Feenstra (1989), the first-order conditions (1) and (2) are parametrized with $\log$-linear functional forms, so that the pricing equations for the two firms in industry $i$ are expressed as: 
(3)

$$
p_{i t}=\mu_{i t}+c_{i t}+\beta p_{i t}^{*}+\alpha y_{t}
$$

$$
p_{i t}^{*}=\mu_{i t}^{*}+\phi e_{t}+c_{i t}^{*}+\beta^{*} p_{i t}+\alpha^{*} y_{t}
$$

where lower case variables denote the log of the corresponding upper-case variable; e.g. $p=$ $\log (P) .^{6}$ The parameters $\mu$ and $\mu^{*}$ are the domestic and foreign price-cost markups, $\phi$ denotes the extent of exchange-rate pass-through, and $\beta$ and $\beta^{*}$ parametrize the simultaneity between import and domestic prices. Note that $\phi$ is defined so that a value of $\phi=-1$ means that movements in costs which result from exchange rates are fully passed on to prices, while $\phi=$ 0 indicates that there is no pass-through at all, so that the foreign firm prices completely to market. As indicated in (3) and (4), the markups of price over marginal costs, $\mu$ and $\mu^{*}$, are allowed to vary over time.

Taking logs, the cost function and marginal costs are:

$$
i c=a+\theta t+\alpha_{h} p_{k}+\alpha_{p} p_{p}+\alpha_{n} p_{n}+\alpha_{e} p_{e}+\alpha_{m} p_{m}+\gamma q
$$

$$
c=a+\log \gamma+\theta t+\alpha_{k} p_{k}+\alpha_{p} p_{p}+\alpha_{n} p_{n}+\alpha_{e} p_{e}+\alpha_{m} p_{m}+(\gamma-1) q
$$

Equation (6) is then substituted into (3) to obtain the pricing equation for a domestic industry. The model is estimated using data at the four-digit level of the 1972 SIC classification,

\footnotetext{
${ }^{6}$ To streamline the notation, I do not write out the complete expressions for domestic and foreign marginal costs, $\mathrm{c}$ and $\mathrm{c}^{*}$.
} 
with observations pooled across nineteen two-digit industries. For example, the data for industry 22, Textile Mill Products, include 78 observations from nine four-digit industries. This pooling is necessary because disaggregated import prices are available for only a relatively short span of years, 1978 to 1988 . Because of the limited degrees of freedom, I assume that all four-digit products within a two-digit industry share common parameters for returns to scale, $\gamma$; price-cost markups, $\mu$ and $\mu^{*}$; and exchange rate pass-through $\phi$. For both domestic and foreign goods, however, I allow productivity growth to vary by four-digit industry. This means that the cost functions for a two-digit industry $i$ are enhanced to include individual trend parameters for each of the $j$ underlying four-digit industries; this adds a $j$ subscript to the productivity parameters, which become $\theta_{\mathrm{j}}$ and $\theta_{\mathrm{j}}^{*}$.

To isolate sector-specific price shifts from changes in the aggregate price level, all prices are first divided by the GDP deflator. As is typical, it turns out that product and factor prices and quantities as well as the exchange rate and GDP are integrated variables, so the model is estimated in first-differences. ${ }^{7}$ The price-cost markups, $\mu$ and $\mu^{*}$, are subsumed into the constant, while in differences, the four-digit productivity trends become industry-specific fixed effects, $\theta$ and $\theta^{*}$. One consequence of this is that it is not possible to disentangle the price-cost markup for a two-digit industry from the four-digit-specific productivity parameters.

\footnotetext{
${ }^{7}$ An alternative approach to simply differencing all variables would be to model any long-run cointegrating relationships in the data, as in Feenstra, Gagnon, and Knetter (1993). For example, it would be reasonable to expect prices and costs in each country to move together, and possibly for domestic prices and import prices to exhibit similar comovements. Unfortunately, the econometric techniques for cointegration with panel data remain to be developed, and it would be difficult in any case to reject non-cointegration with the short time series available for import prices. My/ results in first differences should be interpreted as representing the short-run (within one year) efferts of price and exchange rate movements. Using quarterly data for autos, trucks, and motorcycles, Feenstra (1989) finds that the full extent of exchange-rate pass-through is typically reached within three quarters.
} 
The complete model for a two-digit industry $i$ which encompasses $j$ four-digit categories includes three estimating equations: domestic prices, import prices, and domestic costs: ${ }^{8}$

$$
\begin{aligned}
\Delta p_{t}= & \Delta \mu_{t}+\alpha_{k} \Delta p_{k}+\alpha_{p} \Delta p_{p}+\alpha_{n} \Delta p_{n}+\alpha_{e} \Delta p_{e}+\alpha_{m} \Delta p_{m}+(\gamma-1) \Delta q_{t}+ \\
& +\theta_{j}+\beta \Delta p_{t}^{*}+\alpha y_{t}+\epsilon_{p}
\end{aligned}
$$

$$
\Delta p_{t}^{*}=\Delta \mu_{t}^{*}+\phi \Delta e_{t}+\theta_{j}^{*}+\beta^{*} \Delta p_{t}+\alpha^{*} y_{t}+\epsilon_{p}
$$

(9) $\Delta t c_{t}=\alpha_{k} \Delta p_{k}+\alpha_{p} \Delta p_{p}+\alpha_{n} \Delta p_{n}+\alpha_{e} \Delta p_{e}+\alpha_{m} \Delta p_{m}+\gamma \Delta q_{t}+\theta_{j}+\epsilon_{c}$

The multivariate normal error terms, $\epsilon_{\mathrm{p}}, \epsilon_{\mathrm{p}^{*}}$, and $\epsilon_{\mathrm{c}}$ represent random mistakes made by firms in price-setting and cost-minimizing.

Equations (7) - (9) are estimated jointly using three-stage least-squares (3SLS). I impose the restriction of homogeneity in costs; that is, $\alpha_{k}+\alpha_{p}+\alpha_{n}+\alpha_{e}+\alpha_{m}=1$. Preliminary estimation indicated that this is not rejected for nearly all industries. Note that in differences the price-cost markups become the constant terms in equations (7) and (8).

I must also ensure that there are sufficient identifying restrictions for domestic price, $p$, import price, $p^{*}$, and domestic quantity, $q$, all of which are endogenous variables which enter on the right-hand-side of one or more equations. The two prices are already identified by the structure of the model: factor prices directly affect $p$ but not $p^{*}$, while the exchange rate enters only into the equation for $p^{*}$. I also use interactions of exchange rate growth with

\footnotetext{
${ }^{8}$. ${ }_{0}$ streamline the notation, I suppress all $i$ subscripts as well as $t$ subscripts for factor prices.
} 
four-digit industry dummies as additional instruments for import prices, $p^{*}$; this takes advantage of the possibility that exchange rate pass-through, and thus the reaction of prices, might vary across four-digit industries. ${ }^{9}$ Finally, economy-wide demand aggregates are wellsuited as instruments for domestic demand in each four-digit industry, $q$. In addition to GDP, $y$, I add the growth rate of unemployment as an additional instrument for $q .^{10}$

\section{Data}

Annual data on domestic product prices and quantities, along with factor çuantities and prices at the four-digit level of the 1972 SIC classification come from the NBER Productivity Database. Following the documentation provided by Bartelsman and Gray (1994), I divide materials into energy and non-energy components, and divide labor costs into hours of production workers and the number of non-production employees. The price of capital is not directly contained in the database, but is calculated as in Bartelsman, Caballero, and Lyons (1994), following the Hall-Jorgenson user cost of capital approach."

Consistent measures of disaggregated import prices are surprisingly difficult to obtain - explicit price indices are available from the BLS and Census Bureau for only a limited number of industries and years at the four-digit level of the SIC classification. Even for two-digit industries, most import price series start in 1978 or later. To overcome this

\footnotetext{
${ }^{9}$ In the sensitivity analysis in Section VI, these interactions are entered directly as right-handside variables in the foreign pricing equation (8).

${ }^{10}$ Since I estimate the regressions using TSP, all exogenous variables are used as instruments in each equation. My results are robust to a variety of other instruments such as the level rather than change of unemployment, as well as measures of the output gap.

"For details, see Bartelsman, Caballero, and Lyons (1994).
} 
limitation, I construct import unit-values from data on import values and quantities from the UN Cornmodity Trade Statistics (Series D). These data are available in a consistent form from 1978 to 1988 at the four-digit level of the SITC Revision 2 classification. Though these are of course subject to the usual issues of shifting product quality inherent in unit-values, the data are quite disaggregated--some 841 products at the four-digit level--so that this will hopefully minimize these problems. I discuss sensitivity analysis in Section VI.

The SITC2 classification differs substantially from the SIC; for example, it includes both rav materials and manufactures. Fortunately, it is also more detailed at the four-digit level, so that it is possible to concord the SITC data into the SIC classification, for which 450 4-digit categories are available in the NBER dataset. I use import values as weights for the cases when multiple SITC categories concord into a single SIC category. One minor complication is that in converting from SITC to SIC, the availability of concordances meant that I first converted the SITC trade data to the 1987 SIC classification, and then to the 1972 classification in order to match the NBER Productivity database. As before, this second step is not difficult, since it again goes to a (slightly) less-detailed classification. I once again use import-weights when multiple SIC 1987 categories concord into a single SIC 1972 category. All prices are then rebased to $1987=100$. As summarized in Table 1, after first-differencing, I am left with 1588 observations for import price growth, with coverage for 19 of 20 two-digit SIC industries.

Despite the multiple steps involved, for the categories for which true four-digit SIC data on import prices are available from the BLS (31 out of 229 four digit industries, for a total of 199 observations), the correlation between the levels of the BLS data and the import 
prices based on the UN trade data is 0.747 , while the correlation between the growth rates is 0.450. This provides some hope that the process described above has not introduced too much noise into the import price data. ${ }^{12}$

For the exchange rate, I use a measure which aggregates the value of the dollar against the seven largest U.S. trading partners, where the seven exchange rates are weighted in each year by the volume of each country's bilateral trade with the U.S. The reason behind using bilateral trade weights is illustrated by considering the importance of US-Canada trade flows-these would be severely under-weighted by using multilateral trade-weights or a GDPweighted exchange rate. Each exchange rate is adjusted for relative CPI growth before being aggregated to form a single series for the real US exchange rate. This series is shown in Figure 1, along with the multilateral trade-weighted real exchange rate from the Economic Report of the President. Though the series are quite similar, using bilateral weights provides a somewhat moderated view of the rise and fall of the dollar. Finally, US aggregate income is per-capita real GDP (1987 dollars) from the NIPA accounts.

For each of the 19 two-digit industries, Table 1 shows the number of observations and the number of underlying four-digit industries (SIC industry 25 , furniture, is omitted due to lack of data on import prices). The right three columns of Table 1 show correlations between the growth rates of import prices, domestic prices, and the real exchange rate. The first of these columns shows that import and domestic prices move together in most industries, though this effect is particularly large in only petroleum (29) and primary metals (33), with small but

\footnotetext{
${ }^{12}$ Further evidence is provided by Shiells (1991), who finds that using import unit-values instead of import-price indexes does not greatly affect estimated import-demand elasticities in quarterly U.S. data from 1978 to 1988 .
} 
still notable price co-movements in food (20), textiles (22), apparel (23), lumber (24), chemicals (28), and non-electrical machinery (35). Of course this simple data description does not say anything about the direction of causality between domestic and import prices-this is the point of structural estimation of the model.

The next column provides evidence for the incomplete pass-through of exchange rate movements. The negative correlation with exchange rate changes indicates that import prices in all industries tend to fall with an appreciation of the dollar, but the correlations are generally small--import prices certainly do not appear to move one-to-one with exchange rates. Finally, the right-most column of Table 1 shows that domestic prices are also only moderately correlated with exchange rate movements; further, there is no clear pattern to the signs.

\section{Estimation Results}

Tables 2 and 3 contain regression results for estimation of equations (7) to (9). As discussed above, the three equations are estimated jointly using three-stage least-squares.

Table 2 contains the $\mathrm{R}^{2}$ statistics for the 3 SLS regressions, as well as for the first-stage regressions which provide the instrumental variables estimates of domestic prices, import prices, and domestic quantities. As can be seen in the three columns on the right of the table, these instrumenting regressions generally work well, even for those industries such as leather, apparel, and electrical machinery in which the corresponding structural estimates do not explain much of the variation in the data (particularly for import prices).

The fit of the structural equations, on the other hand, varies somewhat more across the 
two-digit industries. In particular, for most industries, estimation of equation (8) explains only a small portion of the variation in import prices; this is not surprising given the lack of detailed cost data for imports. As would be expected, estimation of equation (7) explains much more of the variation in domestic prices. The cost equations (9) generally fit quite well, so that it is probably not necessary to elaborate on the Cobb-Douglas functional form.

The last column in Table 2 shows the significance levels for a Hausman test of the null hypothesis that the coefficients from the 3SLS estimates are the same as those from estimation of the equations by Seemingly Unrelated Regressions (SUR). Since the SUR estimates do not take into account the simultaneity between import prices, domestic prices, and import quantities, rejection of the null (indicated by a low significance level) implies that there are in fact important feedbacks between these variables. However, I can reject the null at the $5 \%$ level for only 8 of 19 industries (the tobacco industry barely misses with a $5.3 \%$ significance level); this provides initial evidence that there may not be large spillcvers between prices.

Table 3 provides parameter estimates for all three equations. The first colımn is for estimates of the "competing goods effect" parameter, $\beta$; this measures the impact of import prices on domestic prices. Note that these estimates control for the effects of costs, the business cycle (by including GDP growth), as well as the simultaneous impact of domestic prices on import prices. This competing goods effect parameter is positive and significant at the $5 \%$ confidence level for nine industries: food, textiles, chemicals, petroleum, leather, primary metals, non-electrical machinery, transport equipment, and miscellaneous manufactures. Except in the leather industry, however, the magnitudes of the coefficients are 
quite small. In chemicals, for example, a $10 \%$ increase in import price growth leads to only a $0.8 \%$ increase in domestic price growth.

The second column of results provides the elasticity of total costs with respect to output, $\gamma$. As noted before, a value of $\gamma<1$ indicates the presence of increasing returns to scale, since it means that costs do not rise proportionately with output. For 11 of 19 industries, I cannot reject a null hypothesis of constant returns $(\gamma=1)$. On the other hand, it is interesting to note that the non-CRS industries are clustered towards the bottom of the table in the "heavier" range of the manufactures, including for example metal, metal products, and machinery. This is consistent with Morrison (1990), who relates returns to scale to measures of underutilized capacity, which is probably an issue in these industries.

I omit results for the constant, which indicates the average change in price-cost markups, $\Delta \mu$. These are significantly different from zero in only three industries: food and miscellaneous manufactures both show a slight increase in their markups, while in nonelectrical machinery there is a slight decline in the average markup. On the whole, though, these results indicate that markups were roughly constant over this period. Unless there were large changes in demand elasticities, this implies that behavior was roughly constant. This means that my assumption of Bertrand behavior is likely to be innocuous, since any deviations from this benchmark would be evenly eliminated by the differencing.

The next two columns of Table 3 provide coefficients from the import price equation (8): the effect of domestic prices on import prices, $\beta^{*}$, and the extent of exchange rate passthrough $\phi$. In contrast to the modest effects of imports on domestic prices, the third column of resulis in Table 3 shows that import prices in many industries respond markedly to changes 
in domestic prices. In 16 of 19 industries, I find that changes in domestic prices result in a large positive impact on import prices, with the effect statistically significant in eight of these. Electrical machinery is an odd exception: a $1 \%$ increase in domestic prices leads to a statistically significant $2.8 \%$ fall in import prices.

As in the literature discussed in Section II, I find strong evidence for incomplete passthrough of exchange rates: the coefficient $\phi$ is negative but less than one in absolute value in 16 of 19 industries. I can reject complete pass-through $(\phi=-1)$ in all but the seven industries of lumber, paper, petroleum, metal products, transport equipment, instruments, and miscellaneous manufactures, while in 15 of 19 industries I cannot reject the null hypothesis that there is zero pass-through of exchange rates to import prices $(\phi=0)$. If anything, then, my results indicate that controlling for the simultaneity of import prices and domestic prices gives measures of pass-through which are smaller than previous studies. This accords well with the finding of a modest competing goods effect but a large impact of domestic prices on imports, since it means that a part of the change in import prices which is usually attributed to exchange-rate pass-through is actually the result of the simultaneity between import prices and domestic prices. $^{13}$

Finally, the last column of Table 3 shows the total impact of an exchange-rate shock on domestic prices in the U.S.; as discussed above, this depends on both the pass-through of exchange rates to import prices and the simultaneity between import prices and domestic

\footnotetext{
${ }^{13}$ This might be thought of as follows: import prices rise in response to a dollar appreciation (though not fully), and thus cause domestic prices to rise slightly. The simultaneity between the two prices then means that import prices will rise yet again in response to the increase in domestic prices. Neglecting this simultaneity thus provides a small upwards bias to pass-through coefficients in singleequation regressions of the effect of exchange rates on import prices.
} 
prices. The total effect is obtained by substituting the import price equation (8) into the equation for domestic prices (7): ${ }^{14}$

$$
\frac{d p^{\prime}}{d \epsilon^{\prime}}=\frac{\beta \phi}{1-\beta \beta^{*}}
$$

For all industries, I find only a small impact of exchange rates on domestic prices; the effect is statistically significant only in the food industry. This lack of responsiveness of domestic prices is not surprising, since the competing goods effect, $\beta=\mathrm{d} p / \mathrm{d} p^{*}$, is zero or small for most industries, while exchange rate pass-through, $\phi=\mathrm{d} p * / \mathrm{d} e$, is typically less than complete. Putting these together, then, implies that movements in the exchange value of the dollar do not have a substantial impact on U.S. inflation.

\section{Sensitivity Analysis}

My results are robust to a number of changes in the specification. In Table 4, I add interactions of exchange rate growth with four-digit industry dummies to the import price equation (8), rather than simply using these as instruments. This allows for the possibility that the effect of exchange rates on import prices varies across four-digit industries, though at the cost of losing the interpretation of $\phi$ as representing pass-through at the two-digit level (as well as degrees of freedom, which are scarce in some industries). As can be seen in Table 4, the fit of the import price equation improves, but the results remain essentially unchanged: import prices have only small effects on domestic prices, with much larger coefficients in the

\footnotetext{
${ }^{14}$ The coefficients and standard errors are from the TSP analyz command, which linearizes the non-linear functions around the estimated parameter values.
} 
other direction. In results not shown, I add a separate set of four-digit industry fixed effects to the domestic price equation (7); this allows domestic price-cost markups to vary at the four-digit level. Once again, however, the results are essentially unchanged.

I also experimented with adding a post-1985 dummy to the import price equation, both alone and interacted with exchange rate growth (again, I omit the results). This vrould allow for the possibility suggested by Dixit (1989) and Baldwin and Krugman (1989) that the strength of the dollar in 1985 resulted in a form of hysteresis which changed either the pricing regime or the extent of exchange rate pass-through. The post-1985 dummy alone is significant for only two industries (bothwith a negative sign): textiles and electrical machinery. When interacted with exchange rate growth, the post-1985 dummy is significantly different from zero in only 5 of 19 industries. In apparel, primary metals, metal products, and instruments, the coefficient is positive and significant, indicating less pass-through after 1985 , while it is significant and negative for rubber and plastic products, indicating more passthrough. Again, however, these industries are by far the exceptions. Overall, my results provide little evidence of asymmetric adjustment to the dollar's rise and fall.

Finally, in Table 5, I examine the possible bias introduced by using unit values rather than price indexes for import prices. I compare the coefficients obtained from using BLS import price indexes with those from unit values, both for the entire sample as well as for the sub-sample over which price indexes are available. Sufficient data for import price indexes are available to estimate my three-equation system for only four industries: food, lumber, metal products, and non-electrical machinery.

For the first three industries, the results using price indexes are not that different from 
those with unit values. In food and lumber, the effect of domestic prices on import prices remains dramatically larger than the other way around--this result actually gets stronger with price indexes. And the coefficients for exchange rate pass-through and returns to scale are not all that different between the comparable samples using price-indexes and unit values. The result is much the same for metal products: neither $\beta$ nor $\beta^{*}$ are significantly different from zero with the price index data, but the value of the coefficient is larger for the effect of domestic prices on imports than vice-versa. Only in non-electrical machinery do the coefficients obtained with the price indexes differ substantially from the unit-value results (both the entire sample and the sub-sample which matches the price indexes). Even here, however, I find only that neither price affects the other; with both unit-values and import price indexes there is still no evidence for a statistically significant competing goods effect.

\section{Conclusions}

Contrary to the anecdotal evidence, I find only modest evidence for a competing goods effect. While exchange rates and domestic prices influence import prices, import prices do not in turn appear to have a substantial impact on domestic prices. Probably the most important explanation for this result is that U.S. markets are quite competitive to begin with, so that increases in import prices do not provide firms with much breathing room from what is already intensive competition from domestic rivals. Intuitively, equation (7) expresses domestic prices as a function of domestic costs and import prices. If US prices already equal marginal costs, then there is simply little scope for imports which are imperfect substitutes to affect domestic prices. This is consistent with Basu and Fernald (1994), who find only 
modest price-cost markups in two-digit U.S. industries. This explanation is also consistent with the significant (though small) effects of import prices on domestic prices in textiles, primary metals, and transport equipment, all of which faced quantitative import barriers such as quotas or voluntary export restraints over my sample period. As in Krishna (1989), the trade restrictions may have facilitated collusion among domestic firms. This would lead to rents in these industries, and thus provide scope for a significant competing goods effect. Firm-level rather than industry-level data would be useful here to gauge the extent to which firm behavior varies with import competition.

One implication of my results is that since import prices do not have very large effects on U.S. inflation (either directly or indirectly), they are unlikely to have more than a small effect on the growth of domestic factor prices such as wages. My results are thus consistent with those of Lawrence and Slaughter (1993), who document the apparent lack of a Perotstyle wage effect in the U.S. coming from foreign competition.

Finally, my results probably would not extend to other countries, since the competing goods effect is likely to be important for smaller economies in which imports provide substantial competitive pressure on domestic firms (this would also apply to nations moving away from high levels of trade protection). Applying a cross-industry framework across countries would be a promising avenue for further research. 


\section{References}

Bartelsrnan, Eric, Ricardo Caballero, and Richard Lyons, 1994. "Customer- and SupplierDriven Externalities," American Economic Review, September, pp. 1075-1084.

-------, and Wayne Gray, 1994. "NBER Productivity Database," mimeo, September.

Basu, Susanto, and John Fernald, 1994. "Constant Returns and Small Markups in U.S. Manufacturing," Federal Reserve Board International Finance Discussion Paper 483, September.

Ceglowski, Janet, 1992. "Dollar Import Prices and Domestic Prices in the 1980s: A Simultaneous Approach," Bryn Mawr mimeo, December.

Dixit, A.vinash, 1989. "Hysteresis, Import Penetration, and Exchange Rate Pass-through," Quarterly Journal of Economics, vol. 104 no. 2, May, pp. 205-228.

Feenstra, Robert, 1989. "Symmetric Pass-Through of Tariffs and Exchange Rates under Imperfect Competition: An Empirical Test," Journal of International Economics, February, pp. 25-45.

-------, Joseph Gagnon, and Michael Knetter, 1993. "Market Share and Exchange Rate PassT.hrough in World Automobile Trade," Federal Reserve Board International Finance Discussion Paper 446, June.

Feinberg, Robert, 1993. "A Simultaneous Model of Exchange-Rate Passthrough into Prices of Imperfectly Substitutable Domestic and Import Goods," American University mimeo, November.

Fisher, Ëric, 1989. "A Model of Exchange Rate Pass-Through," Journal of International Economics, vol. 26, pp. 25-45.

Froot, Kenneth, and Paul Klemperer, 1989. "Exchange Rate Pass-through when Market Share Matters," American Economic Review, vol. 79, September, pp. 637-54.

Giovannini, Alberto, 1988. "Exchange Rates and Traded Goods Prices," Journal of International Economics, vol. 24, pp. 45-68.

Harrison, Ann, 1992. "Imperfect Explanations for Imperfect Pass-Through: Market Power and Exchange Rates in the US Steel Industry," World Bank mimeo, July.

-------, 1994. "Productivity, Imperfect Competition and Trade Reform: Theory and E'vidence," Journal of International Economics, vol. 36, pp. 53-73. 
Hooper, Peter, and Catherine Mann, 1989. "Exchange Rate Pass-through in the 1980s: The Case of U.S. Imports of Manufactures," Brookings Papers on Economic Astivity, number 1, pp. 297-337.

Knetter, Michael, 1989. "Price Discrimination by U.S. and German Exporters," American Economic Review, vol. 79 (1), March, pp. 198-210.

-------, 1993. "International Comparisons of Pricing-to-Market Behavior," American Economic Review, vol. 83 (3), June, pp. 473-486.

---.---, 1994. "Did the Strong Dollar Increase Competition in U.S. Product Markets?", Review of Economics and Statistics, vol. 76 (1), February, pp. 192-195.

Krishna, Kala, 1989. "Trade Restrictions as Facilitating Practices," Journal of International Economics, vol. 26, May, pp. 251-270.

Krugman, Paul, and Richard Baldwin, 1987. "The Persistence of the U.S. Trade Deficit," Brookings Papers on Economic Activity, number 1, pp. 1-43.

Lawrence, Robert, and Matt Slaughter, 1993. "International Trade and American Wages in the 1980s: Giant Sucking Sound or Small Hiccup?" Brookings Papers on Economic Activity, microeconomics issue, number 2, pp. 161-226.

Levinsohn, James, 1993. "Testing the Imports-as-Market-Discipline Hypothesis," Journal of International Economics, vol. 35, August, pp. 1-22.

Mann, Catherine, 1986. "Prices, Profit Margins and Exchange Rates," Federal Reserve Bulletin, vol. 72, June, pp. 366-379.

Marston, Richard, 1990. "Pricing to Market in Japanese Manufacturing," Journal of International Economics, vol. 29, pp. 217-236.

Morrison, Catherine, 1990. "Market Power, Economic Profitability and Productivity Growth Measurement: An Integrated Structural Approach," NBER working paper 3355, May.

Shiells, Clinton, 1991. "Errors in Import-Demand Estimates Based upon Unit-Value Indexes," Review of Economics and Statistics, vol. 73 no. 2, pp. 378-382. 
Table 1: Summary Statistics

\begin{tabular}{|c|c|c|c|c|c|c|}
\hline \multirow[t]{2}{*}{ SIC } & \multirow[t]{2}{*}{ Industry } & \multirow{2}{*}{$\begin{array}{l}4 \text { digit } \\
\text { SIC's }\end{array}$} & \multirow[t]{2}{*}{ obs } & \multicolumn{3}{|c|}{$\begin{array}{l}\text { correlations between domestic price, } p \text {, } \\
\text { import price, } p^{*} \text {, and exchange rate, e }\end{array}$} \\
\hline & & & & $\mathrm{p}, \mathrm{p}^{*}$ & $\mathrm{p}^{*}, \mathrm{e}$ & $\mathrm{p}, \mathrm{e}$ \\
\hline 20 & Food & 32 & 299 & 0.217 & -0.103 & -0.155 \\
\hline 21 & Tobacco & 3 & 30 & 0.062 & -0.125 & -0.078 \\
\hline 22 & Textile mill products & 9 & 78 & 0.294 & -0.198 & -0.165 \\
\hline 23 & Apparel & 15 & 126 & 0.172 & -0.069 & -0.048 \\
\hline 24 & Lumber and wood products & 8 & 79 & 0.211 & -0.261 & -0.387 \\
\hline 26 & Paper & 6 & 44 & 0.139 & -0.294 & -0.187 \\
\hline 27 & Printing and publishing & 5 & 29 & -0.157 & -0.026 & -0.393 \\
\hline 28 & Chemicals & 23 & 204 & 0.246 & -0.112 & 0.036 \\
\hline 29 & Petroleum refining & 3 & 23 & 0.578 & -0.059 & 0.294 \\
\hline 30 & Rubber and plastic products & 3 & 30 & 0.038 & -0.076 & 0.162 \\
\hline 31 & Leather and leather products & 5 & 30 & -0.0002 & -0.081 & -0.084 \\
\hline 32 & Stone, clay, glass and concrete & 19 & 119 & 0.073 & -0.154 & 0.198 \\
\hline 33 & Primary metal industries & 12 & 93 & 0.541 & -0.155 & -0.314 \\
\hline 34 & Fabricated metal products & 14 & 78 & -0.073 & 0.047 & 0.081 \\
\hline 35 & Machinery, except electrical & 26 & 124 & 0.210 & -0.077 & 0.100 \\
\hline 36 & Electrical machinery & 20 & 82 & -0.026 & -0.152 & -0.047 \\
\hline 37 & Transportation equipment & 9 & 50 & -0.008 & -0.081 & 0.114 \\
\hline 38 & Instruments & 9 & 34 & -0.071 & -0.180 & 0.052 \\
\hline 39 & Miscellaneous & 7 & 36 & 0.102 & -0.036 & -0.113 \\
\hline
\end{tabular}

Note: Price growth is measured relative to GDP deflator. 
Table 2: Fit of the Regressions, $\mathbf{R}^{2}$

\begin{tabular}{|c|c|c|c|c|c|c|c|c|}
\hline \multirow{2}{*}{ SIC } & \multirow{2}{*}{ Industry } & \multirow{2}{*}{$\begin{array}{c}\text { Domestic } \\
\text { Price, P } \\
\text { (7) }\end{array}$} & \multirow{2}{*}{$\begin{array}{l}\text { Import } \\
\text { Price, } \mathrm{P}^{*} \\
\text { (8) }\end{array}$} & \multirow{2}{*}{$\begin{array}{c}\text { Domestic } \\
\text { Cost, C } \\
(9)\end{array}$} & \multicolumn{3}{|c|}{ Instrumenting Regressicns } & \multirow{2}{*}{$\begin{array}{c}\text { Hausman } \\
\text { Test } \\
\text { (signif. } \\
\text { level) }\end{array}$} \\
\hline & & & & & $\mathrm{P}$ & $\mathrm{P}^{*}$ & $Q$ & \\
\hline 20 & Food & 0.570 & 0.124 & 0.626 & 0.666 & 0.307 & 0.3 .27 & 0.905 \\
\hline 21 & Tobacco & 0.108 & 0.090 & 0.720 & 0.705 & 0.461 & 0.451 & 0.053 \\
\hline 22 & Textile mill products & 0.520 & 0.206 & 0.887 & 0.597 & 0.425 & 0.415 & 0.127 \\
\hline 23 & Apparel & 0.032 & 0.048 & 0.825 & 0.210 & 0.247 & 0.372 & 0.000 \\
\hline 24 & Lumber and wood products & 0.670 & 0.131 & 0.894 & 0.705 & 0.364 & 0.457 & 0.649 \\
\hline 26 & Paper & 0.559 & 0.129 & 0.620 & 0.756 & 0.335 & 0.319 & 0.000 \\
\hline 27 & Printing and publishing & 0.543 & 0.355 & 0.555 & 0.825 & 0.632 & $0.3: 12$ & 0.042 \\
\hline 28 & Chemicals & 0.581 & 0.099 & 0.657 & 0.509 & 0.311 & 0.233 & 0.046 \\
\hline 29 & Petroleum refining & 0.705 & 0.422 & 0.636 & 0.652 & 0.827 & 0.536 & 0.305 \\
\hline 30 & Rubber and plastic products & 0.473 & 0.028 & 0.845 & 0.648 & 0.503 & 0.859 & 0.000 \\
\hline 31 & Leather and leather products & 0.057 & 0.003 & 0.650 & 0.489 & 0.278 & 0.447 & 0.000 \\
\hline 32 & Stone, clay, glass, concrete & 0.148 & 0.106 & 0.907 & 0.539 & 0.241 & 0.646 & 0.000 \\
\hline 33 & Primary metal industries & 0.703 & 0.362 & 0.805 & 0.751 & 0.554 & 0.517 & 0.090 \\
\hline 34 & Fabricated metal products & 0.391 & 0.254 & 0.869 & 0.883 & 0.830 & 0.540 & 0.407 \\
\hline 35 & Machinery, except electrical & 0.304 & 0.145 & 0.822 & 0.623 & 0.210 & $0.6 \vdots 0$ & 0.407 \\
\hline 36 & Electrical machinery & 0.457 & 0.052 & 0.869 & 0.751 & 0.230 & $0.6{ }^{\prime} 0$ & 0.324 \\
\hline 37 & Transportation equipment & 0.089 & 0.112 & 0.972 & 0.614 & 0.458 & $0.36 i 0$ & 0.000 \\
\hline 38 & Instruments & 0.503 & 0.118 & 0.748 & 0.700 & 0.530 & 0.8519 & 0.834 \\
\hline 39 & Miscellaneous & 0.586 & 0.056 & 0.852 & 0.857 & 0.417 & $0.6 \geq 9$ & 0.723 \\
\hline
\end{tabular}

Note: A small significance level for the Hausman test corresponds to a large $\chi^{2}$ test statistic, and indicates that I can reject the null hypothesis that the 3SLS estimates are not different from the SUR estimates. In other words, a small significance level indicates that instrumenting for domestic prices, import prices, and domestic quantities matters for the estimated coefficients. 
Table 3: Equations for Domestic Prices, Import Prices, and Domestic Costs (Three-Stage Least Squares)

\begin{tabular}{|c|c|c|c|c|c|}
\hline Industry & $\begin{array}{c}\text { Import } \\
\text { price, } \beta p^{*}\end{array}$ & $\begin{array}{l}\text { Returns to } \\
\text { scale, } \gamma\end{array}$ & $\begin{array}{l}\text { Domestic price, } \\
\beta^{*} \mathrm{p}\end{array}$ & $\begin{array}{c}\text { Exchange rate, } \\
\phi \mathrm{e}\end{array}$ & $\begin{array}{c}\text { Exchange rate on } \\
\text { domestic prices, } \\
\beta \phi /\left(1-\beta \beta^{*}\right)\end{array}$ \\
\hline 20 Food & $\begin{array}{l}0.116^{*} \\
(0.042)\end{array}$ & $\begin{array}{c}0.872 \\
(0.103)\end{array}$ & $\begin{array}{l}0.988 * \\
(0.358)\end{array}$ & $\begin{array}{l}-0.302 \\
(0.166)\end{array}$ & $\begin{array}{l}-0.040 * \\
(0.016)\end{array}$ \\
\hline 21 Tobaicco & $\begin{array}{l}-0.160 \\
(0.088)\end{array}$ & $\begin{array}{l}0.314 \ddagger \\
(0.193)\end{array}$ & $\begin{array}{c}2.024 \\
(1.998)\end{array}$ & $\begin{array}{c}0.014 \\
(0.383) \\
\end{array}$ & $\begin{array}{l}-0.002 \\
(0.046)\end{array}$ \\
\hline 22 Textiles & $\begin{array}{c}0.070^{*} \\
(0.030)\end{array}$ & $\begin{array}{c}1.073 \\
(0.054)\end{array}$ & $\begin{array}{c}1.448 * \\
(0.460)\end{array}$ & $\begin{array}{l}-0.257^{*} \\
(0.093)\end{array}$ & $\begin{array}{l}-0.020 \\
(0.012)\end{array}$ \\
\hline 23 Apparel & $\begin{array}{l}-0.058 \\
(0.037)\end{array}$ & $\begin{array}{c}1.010 \\
(0.045)\end{array}$ & $\begin{array}{c}3.089 \\
(1.985) \\
\cdots\end{array}$ & $\begin{array}{l}-0.002 \\
(0.177)\end{array}$ & $\begin{array}{c}0.0001 \\
(0.009)\end{array}$ \\
\hline 24 Lumber & $\begin{array}{l}-0.007 \\
(0.028)\end{array}$ & $\begin{array}{c}0.969 \\
(0.060)\end{array}$ & $\begin{array}{c}1.112 \\
(0.633) \\
\cdots\end{array}$ & $\begin{array}{l}-0.643 * \\
(0.320)\end{array}$ & $\begin{array}{c}0.004 \\
(0.017)\end{array}$ \\
\hline 26 Paper & $\begin{array}{c}0.029 \\
(0.029)\end{array}$ & $\begin{array}{c}1.016 \\
(0.163)\end{array}$ & $\begin{array}{c}0.676 \\
(0.982)\end{array}$ & $\begin{array}{l}-1.189^{*} \\
(0.435)\end{array}$ & $\begin{array}{l}-0.035 \\
(0.038)\end{array}$ \\
\hline 27 Printing & $\begin{array}{l}-0.022 \\
(0.028)\end{array}$ & $\begin{array}{c}0.753 \\
(0.181)\end{array}$ & $\begin{array}{c}1.242 \\
(1.481)\end{array}$ & $\begin{array}{l}-0.011 \\
(0.260)\end{array}$ & $\begin{array}{c}0.0002 \\
(0.005)\end{array}$ \\
\hline 28 Chemicals & $\begin{array}{l}0.081 * \\
(0.021)\end{array}$ & $\begin{array}{c}0.801 \ddagger \\
(0.079)\end{array}$ & $\begin{array}{l}1.527^{*} \\
(0.277)\end{array}$ & $\begin{array}{l}-0.237 \\
(0.211)\end{array}$ & $\begin{array}{c}-0.022 \\
(-1.036)\end{array}$ \\
\hline 29 Petroleum & $\begin{array}{c}0.134^{*} \\
(0.035)\end{array}$ & $\begin{array}{c}0.905 \\
(0.339)\end{array}$ & $\begin{array}{c}0.946 * \\
(0.216)\end{array}$ & $\begin{array}{l}-0.635^{*} \\
(0.282)\end{array}$ & $\begin{array}{l}-0.098 \\
(0.061)\end{array}$ \\
\hline 30 Rubber & $\begin{array}{c}0.005 \\
(0.029) \\
\end{array}$ & $\begin{array}{c}1.094 \\
(0.161) \\
\end{array}$ & $\begin{array}{c}3.032 * \\
(1.461)\end{array}$ & $\begin{array}{l}-0.089 \\
(0.384)\end{array}$ & $\begin{array}{l}-0.0004 \\
(0.003)\end{array}$ \\
\hline 31 Leather & $\begin{array}{c}0.375^{*} \\
(0.116)\end{array}$ & $\begin{array}{c}0.962 \\
(0.070) \\
\end{array}$ & $\begin{array}{l}1.453 * \\
(0.479)\end{array}$ & $\begin{array}{c}0.053 \\
(0.245) \\
\end{array}$ & $\begin{array}{c}0.043 \\
(0.209)\end{array}$ \\
\hline $\begin{array}{l}32 \text { Stone, clay, glass, } \\
\text { concrete }\end{array}$ & $\begin{array}{c}0.061 \\
(0.041)\end{array}$ & $\begin{array}{l}0.753 \ddagger \\
(0.016)\end{array}$ & $\begin{array}{c}0.901 \\
(0.964)\end{array}$ & $\begin{array}{l}-0.272 \\
(0.252)\end{array}$ & $\begin{array}{l}-0.018 \\
(0.023)\end{array}$ \\
\hline 33 Primary metals & $\begin{array}{c}0.143 * \\
(0.044)\end{array}$ & $\begin{array}{l}0.871 \ddagger \\
(0.047)\end{array}$ & $\begin{array}{l}1.163^{*} \\
(0.140)\end{array}$ & $\begin{array}{l}-0.189 \\
(0.186)\end{array}$ & $\begin{array}{l}-0.032 \\
(0.034)\end{array}$ \\
\hline 34 Metal products & $\begin{array}{c}0.0038 \\
(0.0020)\end{array}$ & $\begin{array}{l}0.761 \ddagger \\
(0.096)\end{array}$ & $\begin{array}{l}-0.286 \\
(1.830)\end{array}$ & $\begin{array}{c}1.428 \\
(1.252) \\
\cdots \cdots \cdots\end{array}$ & 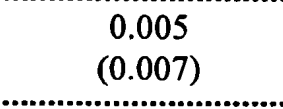 \\
\hline $\begin{array}{l}35 \text { Machinery, non- } \\
\text { electrical }\end{array}$ & $\begin{array}{l}0.067^{*} \\
(0.018)\end{array}$ & $\begin{array}{c}0.906 \ddagger \\
(0.025)\end{array}$ & $\begin{array}{l}3.871^{*} \\
(1.491)\end{array}$ & $\begin{array}{l}-0.208 \\
(0.327)\end{array}$ & $\begin{array}{l}-0.019 \\
(0.031)\end{array}$ \\
\hline $\begin{array}{l}36 \text { Electrical } \\
\text { machinery }\end{array}$ & $\begin{array}{l}-0.033 \\
(0.025)\end{array}$ & $\begin{array}{l}0.829 \ddagger \\
(0.051)\end{array}$ & $\begin{array}{l}-2.828 * \\
(1.040)\end{array}$ & $\begin{array}{l}-0.076 \\
(0.404)\end{array}$ & $\begin{array}{c}0.0028 \\
(0.015)\end{array}$ \\
\hline $\begin{array}{l}37 \text { Transport } \\
\text { equipmeint }\end{array}$ & $\begin{array}{l}0.049 * \\
(0.025)\end{array}$ & $\begin{array}{c}0.927 \\
(0.039)\end{array}$ & $\begin{array}{c}1.345 \\
(3.521)\end{array}$ & $\begin{array}{l}-0.646 \\
(0.568)\end{array}$ & $\begin{array}{l}-0.034 \\
(0.039)\end{array}$ \\
\hline 38 Instruments & $\begin{array}{c}0.026 \\
(0.034) \\
-\end{array}$ & $\begin{array}{c}0.745 \ddagger \\
(0.030)\end{array}$ & $\begin{array}{l}-1.102 \\
(0.718) \\
\end{array}$ & $\begin{array}{l}-0.136 \\
(0.564)\end{array}$ & $\begin{array}{l}-0.003 \\
(0.025)\end{array}$ \\
\hline 39 Misce:llaneous & $\begin{array}{c}0.067^{*} \\
(0.023)\end{array}$ & $\begin{array}{c}0.909 \\
(0.054) \\
\end{array}$ & $\begin{array}{r}2.676 \\
(1.406) \\
\end{array}$ & $\begin{array}{l}-0.183 \\
(0.449) \\
\end{array}$ & $\begin{array}{l}-0.015 \\
(0.037) \\
\end{array}$ \\
\hline
\end{tabular}


Table 4: Sensitivity Analysis: add two-digit exchange rate interactions in inport prices (Three-Stage Least Squares)

\begin{tabular}{|c|c|c|c|c|c|c|c|}
\hline \multirow[b]{2}{*}{ Industry } & \multicolumn{3}{|c|}{ Regression Coefficients } & \multicolumn{3}{|c|}{ Fit of the Regressions, $\mathrm{R}^{2}$} & \multirow[b]{2}{*}{$\begin{array}{l}\text { Hausman Test } \\
\text { (signif. level) }\end{array}$} \\
\hline & $\begin{array}{c}\text { Import } \\
\text { price, } \beta \mathrm{p}^{*}\end{array}$ & $\begin{array}{l}\text { Returns to } \\
\text { scale, } \gamma\end{array}$ & $\begin{array}{l}\text { Domestic } \\
\text { price, } \beta^{*} p\end{array}$ & $\begin{array}{l}\text { Domestic } \\
\text { price, } p\end{array}$ & $\begin{array}{l}\text { Import } \\
\text { price, } \mathrm{p}^{*}\end{array}$ & $\begin{array}{c}\text { Domestic } \\
\text { cost, c }\end{array}$ & \\
\hline 20 Food & $\begin{array}{c}0.072 * \\
(0.037)\end{array}$ & $\begin{array}{c}0.777 \ddagger \\
(0.090)\end{array}$ & $\begin{array}{l}0.913^{*} \\
(0.346)\end{array}$ & 0.620 & 0.214 & 0.637 & 0.815 \\
\hline 21 Tobacco & $\begin{array}{l}-0.153 \\
(0.090)\end{array}$ & $\begin{array}{c}0.315 \ddagger \\
(0.193)\end{array}$ & $\begin{array}{c}1.850 \\
(1.977)\end{array}$ & 0.109 & 0.119 & 0.720 & 0.493 \\
\hline 22 Textiles & $\begin{array}{c}0.055 \\
(0.032)\end{array}$ & $\begin{array}{c}1.087 \\
(0.060)\end{array}$ & $\begin{array}{l}1.495^{*} \\
(0.480)\end{array}$ & 0.503 & 0.237 & 0.887 & 0.015 \\
\hline 23 Apparel & $\begin{array}{l}-0.039 \\
(0.036)\end{array}$ & $\begin{array}{c}1.007 \\
(0.045)\end{array}$ & $\begin{array}{c}4.703 \\
(3.826)\end{array}$ & 0.049 & 0.069 & 0.825 & 0.000 \\
\hline 24 Lumber & $\begin{array}{l}-0.014 \\
(0.028)\end{array}$ & $\begin{array}{c}0.962 \\
(0.060)\end{array}$ & $\begin{array}{c}1.292 * \\
(0.685)\end{array}$ & 0.666 & 0.220 & 0.895 & 0.385 \\
\hline 26 Paper & $\begin{array}{c}0.023 \\
(0.029)\end{array}$ & $\begin{array}{c}1.037 \\
(0.170)\end{array}$ & $\begin{array}{c}0.877 \\
(1.111)\end{array}$ & 0.559 & 0.206 & 0.620 & 0.010 \\
\hline 27 Printing & $\begin{array}{l}-0.024 \\
(0.029)\end{array}$ & $\begin{array}{c}0.757 \\
(0.195)\end{array}$ & $\begin{array}{c}0.802 \\
(1.500)\end{array}$ & 0.553 & 0.518 & 0.549 & 0.010 \\
\hline 28 Chemicals & $\begin{array}{c}0.045 \\
(0.025)\end{array}$ & $\begin{array}{c}0.767 \ddagger \\
(0.080)\end{array}$ & $\begin{array}{l}1.428 * \\
(0.278)\end{array}$ & 0.614 & 0.220 & 0.668 & 0.878 \\
\hline 29 Petroleum & $\begin{array}{l}0.073^{*} \\
(0.036)\end{array}$ & $\begin{array}{c}0.986 \\
(0.382)\end{array}$ & $\begin{array}{l}1.044 * \\
(0.145)\end{array}$ & 0.644 & 0.911 & 0.628 & 0.232 \\
\hline 30 Rubber & $\begin{array}{l}-0.004 \\
(0.030)\end{array}$ & $\begin{array}{l}1.090 \\
(0.166)\end{array}$ & $\begin{array}{l}4.265^{*} \\
(1.821)\end{array}$ & 0.482 & 0.073 & 0.844 & 0.000 \\
\hline 31 Leather & $\begin{array}{l}0.293^{*} \\
(0.111)\end{array}$ & $\begin{array}{c}1.140 \\
(0.156)\end{array}$ & $\begin{array}{l}1.650^{*} \\
(0.712)\end{array}$ & 0.062 & 0.001 & 0.655 & 0.000 \\
\hline $\begin{array}{l}32 \text { Stone, clay, } \\
\text { glass, concrete }\end{array}$ & $\begin{array}{c}0.023 \\
(0.045)\end{array}$ & $\begin{array}{c}0.755 \ddagger \\
(0.017)\end{array}$ & $\begin{array}{c}0.408 \\
(1.452)\end{array}$ & 0.152 & 0.212 & 0.907 & 0.000 \\
\hline 33 Primary metals & $\begin{array}{c}0.127 * \\
(0.043)\end{array}$ & $\begin{array}{c}0.840 \ddagger \\
(0.049)\end{array}$ & $\begin{array}{l}1.223 * \\
(0.195)\end{array}$ & 0.705 & 0.406 & 0.808 & 0.999 \\
\hline 34 Metal products & $\begin{array}{c}0.005^{*} \\
(0.002)\end{array}$ & $\begin{array}{l}0.761 \ddagger \\
(0.096)\end{array}$ & $\begin{array}{l}-2.700 \\
(5.230)\end{array}$ & 0.390 & 0.746 & 0.869 & 0.550 \\
\hline $\begin{array}{l}35 \text { Machinery, } \\
\text { non-electrical }\end{array}$ & $\begin{array}{c}0.044^{*} \\
(0.019)\end{array}$ & $\begin{array}{c}0.890 \ddagger \\
(0.029)\end{array}$ & $\begin{array}{l}-2.889 \\
(4.245)\end{array}$ & 0.373 & 0.130 & 0.824 & 0.987 \\
\hline $\begin{array}{l}36 \text { Electrical } \\
\text { machinery }\end{array}$ & $\begin{array}{l}-0.023 \\
(0.026)\end{array}$ & $\begin{array}{l}0.825 \ddagger \\
(0.053)\end{array}$ & $\begin{array}{l}-0.385 \\
(2.964)\end{array}$ & 0.469 & 0.124 & 0.870 & 0.379 \\
\hline $\begin{array}{l}37 \text { Transport } \\
\text { equipment }\end{array}$ & $\begin{array}{c}0.044 \\
(0.027)\end{array}$ & $\begin{array}{c}0.917 \\
(0.047)\end{array}$ & $\begin{array}{l}6.178 \\
(5.916)\end{array}$ & 0.087 & 0.111 & 0.972 & 0.722 \\
\hline 38 Instruments & $\begin{array}{c}0.030 \\
(0.033)\end{array}$ & $\begin{array}{c}0.749 \ddagger \\
(0.029)\end{array}$ & $\begin{array}{l}-1.306 \\
(1.024)\end{array}$ & 0.504 & 0.188 & 0.747 & 0.538 \\
\hline 39 Miscellaneous & $\begin{array}{c}0.067^{*} \\
(0.022)\end{array}$ & $\begin{array}{c}0.903 \\
(0.055)\end{array}$ & $\begin{array}{c}1.794 \\
(1.632)\end{array}$ & 0.592 & 0.142 & 0.853 & 0.712 \\
\hline
\end{tabular}


Table 5: Sensitivity Analysis

Results with Import Unit Values vs. BLS Import Price Index

(Three-Stage Least Squares)

\begin{tabular}{|c|c|c|c|c|c|}
\hline Industry & & $\begin{array}{c}\text { Import price, } \\
\beta \mathrm{p}^{*}\end{array}$ & $\begin{array}{l}\text { Domestic } \\
\text { Price, } \beta^{*} \text { p }\end{array}$ & $\begin{array}{l}\text { Exchange } \\
\text { Rate, } \phi \mathrm{e}\end{array}$ & $\begin{array}{l}\text { Returns to } \\
\text { scale, } \gamma\end{array}$ \\
\hline \multirow[t]{3}{*}{20 Food } & $\begin{array}{l}\text { Import unit values, } \\
\text { all observations (299) }\end{array}$ & $\begin{array}{l}0.116^{*} \\
(0.042)\end{array}$ & $\begin{array}{l}0.988^{*} \\
(0.358)\end{array}$ & $\begin{array}{l}-0.302 \\
(0.166)\end{array}$ & $\begin{array}{c}0.872 \\
(0.103)\end{array}$ \\
\hline & $\begin{array}{l}\text { Import unit values, but only if } \\
\text { import index exists (49) }\end{array}$ & $\begin{array}{l}-0.116^{*} \\
(0.036)\end{array}$ & $\begin{array}{l}2.173^{*} \\
(0.397)\end{array}$ & $\begin{array}{l}-0.106 \\
(0.157)\end{array}$ & $\begin{array}{c}1.053 \\
(0.117)\end{array}$ \\
\hline & $\begin{array}{l}\text { BLS Import price index, } \\
49 \text { observations }\end{array}$ & $\begin{array}{l}-0.060 \\
(0.032)\end{array}$ & $\begin{array}{l}3.254^{*} \\
(0.526)\end{array}$ & $\begin{array}{l}-0.134 \\
(0.195)\end{array}$ & $\begin{array}{c}0.938 \\
(0.128)\end{array}$ \\
\hline \multirow[t]{3}{*}{24 Lumber } & $\begin{array}{l}\text { Import unit values, } \\
\text { all observations (79) }\end{array}$ & $\begin{array}{l}-0.007 \\
(0.028)\end{array}$ & $\begin{array}{c}1.112 \\
(0.633)\end{array}$ & $\begin{array}{l}-0.643^{*} \\
(0.320)\end{array}$ & $\begin{array}{c}0.969 \\
(0.060)\end{array}$ \\
\hline & $\begin{array}{l}\text { Import unit values, but only if } \\
\text { import index exists ( } 20)\end{array}$ & $\begin{array}{c}0.037 \\
(0.055)\end{array}$ & $\begin{array}{c}0.494 \\
(0.323)\end{array}$ & $\begin{array}{l}-0.341 \\
(0.176)\end{array}$ & $\begin{array}{c}0.856 \\
(0.130)\end{array}$ \\
\hline & $\begin{array}{l}\text { BLS Import price index, } \\
20 \text { observations }\end{array}$ & $\begin{array}{l}0.149^{*} \\
(0.057)\end{array}$ & $\begin{array}{l}1.227^{*} \\
(0.168)\end{array}$ & $\begin{array}{l}-0.246 \\
(0.115)\end{array}$ & $\begin{array}{c}0.885 \\
(0.086)\end{array}$ \\
\hline \multirow[t]{3}{*}{$\begin{array}{l}34 \text { Metal } \\
\text { Products }\end{array}$} & $\begin{array}{l}\text { Import unit values, } \\
\text { all observations }(78)\end{array}$ & $\begin{array}{l}0.004^{*} \\
(0.002)\end{array}$ & $\begin{array}{l}-0.286 \\
(1.830)\end{array}$ & $\begin{array}{c}1.428 \\
(1.252)\end{array}$ & $\begin{array}{l}0.761 \ddagger \\
(0.096)\end{array}$ \\
\hline & $\begin{array}{l}\text { Import unit values, but only if } \\
\text { import index exists (20) }\end{array}$ & $\begin{array}{c}0.002 \\
(0.016)\end{array}$ & $\begin{array}{l}6.804^{*} \\
(2.556)\end{array}$ & $\begin{array}{l}-0.205 \\
(0.259)\end{array}$ & $\begin{array}{c}0.970 \\
(0.045)\end{array}$ \\
\hline & $\begin{array}{l}\text { BLS Import price index, } \\
20 \text { observations }\end{array}$ & $\begin{array}{l}-0.037 \\
(0.053)\end{array}$ & $\begin{array}{c}0.474 \\
(0.983)\end{array}$ & $\begin{array}{l}-0.614^{*} \\
(0.063)\end{array}$ & $\begin{array}{c}0.958 \\
(0.041)\end{array}$ \\
\hline \multirow{3}{*}{$\begin{array}{l}35 \\
\text { Machinery, } \\
\text { non- } \\
\text { electrical }\end{array}$} & $\begin{array}{l}\text { Import unit values, } \\
\text { all observations (124) }\end{array}$ & $\begin{array}{l}0.067^{*} \\
(0.018)\end{array}$ & $\begin{array}{l}3.871^{*} \\
(1.491)\end{array}$ & $\begin{array}{l}-0.208 \\
(0.327)\end{array}$ & $\begin{array}{l}0.906 \ddagger \\
(0.025)\end{array}$ \\
\hline & $\begin{array}{l}\text { Import unit values, but only if } \\
\text { import index exists ( } 33 \text { ) }\end{array}$ & $\begin{array}{l}0.118^{*} \\
(0.036)\end{array}$ & $\begin{array}{l}3.250 \\
(1.561)\end{array}$ & $\begin{array}{l}-0.347 \\
(0.386)\end{array}$ & $\begin{array}{c}0.775 \ddagger \\
(0.022)\end{array}$ \\
\hline & $\begin{array}{l}\text { BLS Import price index, } \\
33 \text { observations }\end{array}$ & $\begin{array}{l}-0.056 \\
(0.065)\end{array}$ & $\begin{array}{l}-0.124 \\
(0.463)\end{array}$ & $\begin{array}{l}-1.175^{*} \\
(0.097)\end{array}$ & $\begin{array}{l}0.785 \ddagger \\
(0.021)\end{array}$ \\
\hline
\end{tabular}

Notes: 1. robust standard errors in parentheses

2. * = significant at $5 \%$ confidence level

3. $\ddagger=$ significantly different from 1.0 at $5 \%$ confidence level 


\section{Figure 1}

\section{Exchange Value of the Dollar (adjusted for inflation)}

Bilateral vs. Multilateral Trade Weights

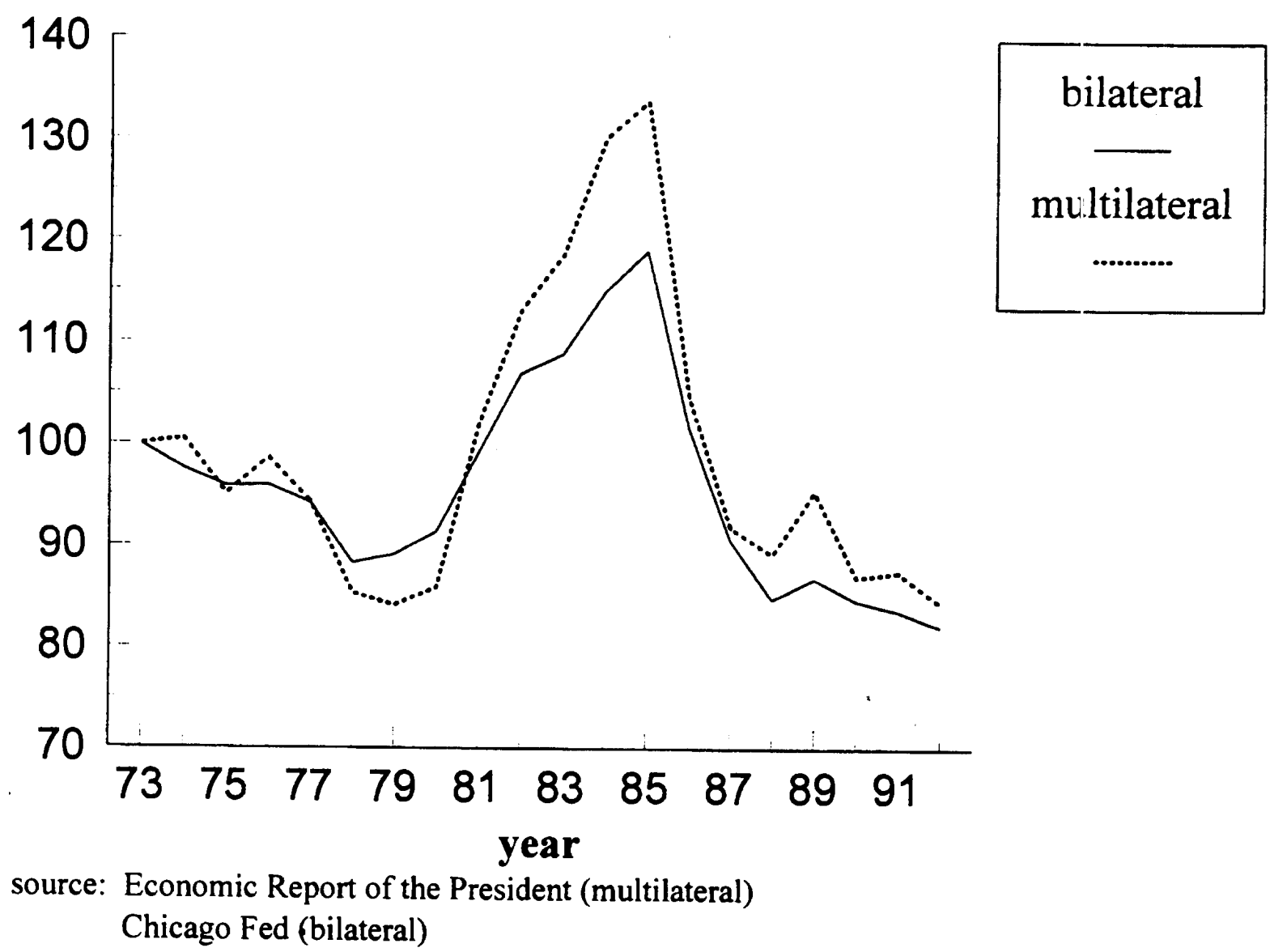




\section{International Finance Discussion Papers}

IFDP

Number

Titles

Author(s)

1995

508 Import Prices and the Competing Goods Effect

Phillip Swagel

507 Supply-side Economics in a Global Economy

Enrique G. Mendoza

Linda L. Tesar

506 The Lucas Critique In Practice: Theory Without Measurement

Neil R. Ericsson

John S. Irons

505 Real Exchange Rate Targeting and Macroeconomic Instability

Martin Uribe

504 Inferences from Parametric and Non-Parametric Covariance Matrix Estimation Procedures

Wouter J. Den Haan

Andrew T. Levin

Martin Uribe

502 Strategic Returns to International

Diversification: An Application to the Equity

Markets of Europe, Japan, and North America

John Ammer

Jianping Mei

501 Real Exchange Rate Movements in High Inflation Countries

John H. Rogers

Ping Wang

500 Political Competition, Casual Relations Between

Diane Lim Rogers

Taxes and Spending, and Their Influence on

Government Size: Evidence From State-Level Data

John H. Rogers

499 International Stock Price Spillovers and Market Liberalization: Evidence From Korea, Japan, and the United States

Sang W. Kim

John H. Rogers

$498 \quad$ How Wide is the Border?

Charles Engle

John H. Rogers

497 Constrained Suboptimality in Economies with Limited Communication

David Bowman

496 Saving-Investment Associations and Capital Mobility On the Evidence from Japanese Regional Data

Robert Dekle

Please address requests for copies to International Finance Discussion Papers, Division of Internaticnal Finance, Stop 24, Board of Governors of the Federal Reserve System, Washington, D.C. 20551. 


\section{International Finance Discussion Papers}

IFDP

Number

Titles

Author(s)

1995

495 Convertibility Risk, Default Risk, and the Mexdollar Anomaly

John H. Rcgers

494 Government Budget Deficits and Trade Deficits Are Present-Value Constraints Satisfied in Long-Term Data?

Shaghil Ahined

John H. Rogers

493 Real Shocks and Real Exchange Rates in Really Long-Term

John H. Rogers

1994

492 Loss Aversion in a Consumption/Savings Model

David Bow'man Deborah Minehart Matthew Rabin

491 Terms-of-Trade Uncertainty and Economic Growth: Are Risk Indicators Significant in Growth Regressions

Enrique G. Mendoza

490 Politics, Economics, and Investment: Explaining Plant and Equipment Spending by U.S. Direct Investors in Argentina, Brazil, and Mexico

489 On The Dynamic Properties of Asymmetric Models of Real GNP

488 A distributed block approach to solving near-block-diagonal systems with an application to a large macroeconometric mode

Jon Faust

Ralph Trycn

487 Conditional and Structural Error Correction Models

Neil R. Ericsson

486 Bank Positions and Forecasts of Exchange Rate Movements

Michael P. Leahy

485 Technological Progress and Endogenous Capital

Depreciation: Evidence from the U.S. and Japan

Robert Dekle

$484 \quad$ Are Banks Market Timers or Market Makers? Explaining Foreign Exchange Trading Profits

John Ammer

Allan D. Biunner

483 Constant Returns and Small and Markups in U.S.

Manufacturing

John G. Fe:nald

Suanto Bası

482 The Real Exchange Radiant Fiscal Policy During the Gold Standard Period: Evidence from the United States and Great Britain

Graciela L. Kaminsky Michael Klein 